\title{
Security and Religion: The Discursive Self-legitimation of the Chechen Authorities
}

\author{
Marat Iliyasov \\ University of St Andrews, St Andrews, UK \\ mi29@st-andrews.ac.uk
}

\begin{abstract}
This article analyses the official discourse of the Chechen authorities and posits that it reflects the government's efforts as self-legitimation. This investigation seeks to identify the mechanisms exploited by the Chechen regime to boost self-legitimacy by examining the 'News' programme on the Chechen state television channel 'Grozny', which, in the authoritarian setting of Chechnya, became the government's mouthpiece and a propagator of official discourse. To provide for the context and to boost findings, the study is complemented by a discursive analysis of one more historicalpolitical television programme and a political advertisement that was broadcast by the same channel during the period in which the fieldwork took place. The collected data is processed using Critical Discourse Analysis.
\end{abstract}

\section{Keywords}

Chechnya - Kadyrov - security - religion - discourse - legitimation - regime

\section{Introduction}

On 16 April 2018, the Chechen Republic celebrated its 'Day of Peace' for the ninth time. This date marks the end of counter-terrorism operations in Chechnya by the then president of the Russian Federation, Dmitry Medvedev, in 20o9. The celebration started in the Chechen capital Grozny with a conventional march of tens of thousands of people bearing Chechen and Russian flags, various posters with Soviet-style slogans, and portraits of the republic's 'holy trinity', the Russian President Vladimir Putin, the Republic's current 
leader Ramzan Kadyrov, and his late father Akhmat Kadyrov. ${ }^{1}$ After the procession and a solemn ceremony to honour the memory of Akhmat Kadyrov, the republic's leadership met with high-ranking members of the security forces and the administration's officials in Grozny's main concert hall. In their speeches, Ramzan Kadyrov and his associates reiterated the government's achievements in security and nation-building ("News", 27 April 2018).

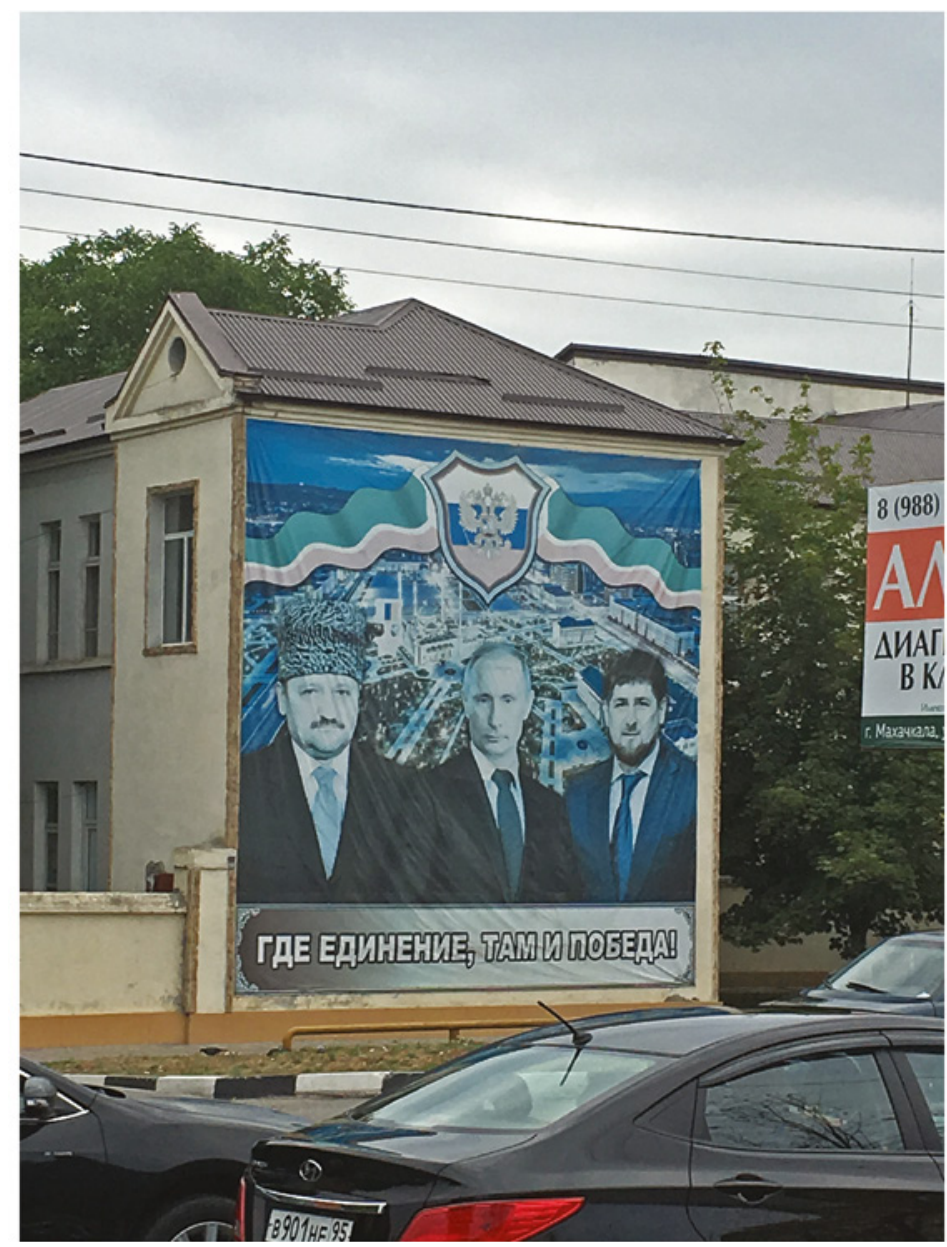

FIGURE 1 The portraits of the "holy trinity" embellish many buildings in the Chechen capital Grozny AUTHOR'S PERSONAL PHOTO

1 This nickname originates from the practice of hanging the portraits of these three politicians together in the republic's public places and offices. 
This 'show', with its massive rally, pretentious ceremonies and pompous speeches, presented by the 'Novosti' (Russian for News) programme on the Chechen state television channel Grozny (hereafter Grozny TV), encapsulated the official discourse that aims to legitimise Chechnya's current authoritarian government. Using the theoretical-methodological approach of Critical Discourse Analysis/CDA (Van Dijk, 2001; Fairclough and Wodak, 1997), this article answers the question, what mechanisms do Chechen authorities use to support self-legitimation and what sources do they refer to in their claims to legitimacy? In response, it analyses the official discourse of the republic's authorities communicated through Grozny TV. The research mainly focuses on the 'News' programme, which was watched regularly during five consequent months from January to May 2018. This exploration is supported by the discursive analysis of the historical-political programme 'Illiusia' (Russian for Illusion) and a political advertisement that was broadcast right after the 'News' programme by the same channel during the fieldwork period.

The article first provides a context, which explains the Chechen authorities' need for legitimacy. Then, it builds a theoretical framework using approaches that analyse the concepts of discourse and legitimacy used in the article. Next, it presents a research tool based on CDA and, finally, it offers an analysis of the collected data, which makes it possible to identify the mechanism for legitimation and the sources of legitimacy that the regime exploits and refers to.

The Chechen government's lack of legitimacy stems from the origin of the current regime and the methods that it has utilised to maintain power. It is widely known that the current leader of the republic, Ramzan Kadyrov, 'inherited' his position after the death of his father Akhmat Kadyrov, who was appointed acting head of the administration by Moscow during the first months of the second Russo-Chechen war in 2000. Akhmat Kadyrov's decision to abandon his comrades and side with Chechnya's recent enemy made it possible for Russia to implement a Chechenization policy, which aimed to establish Chechnya's loyalty to the regime in Moscow (Perovic, 20o6: 4; Ware, 2009) and to evade international criticism by framing the war as a Chechen domestic problem (Cornell, 2005). The appointment of the former mufti [an Arabic term which means spiritual leader] of de facto independent Chechnya as the lawful head of the new pro-Russian administration and his remit to ensure security in the republic served both goals. In 2003, Chechenization was further advanced as the Kremlin attempted to legalise the republic's reincorporation into the 
Russian Federation as well as the appointment of Kadyrov through a referendum and the consequent presidential elections. In the context of ongoing war and the absence of international observers, the results of both were more than doubtful (Souleimanov, 2015), even if they were welcomed by some members of the international community as a 'step towards peace' (Cornell, 2005).

From the start, neither the referendum nor the elections legitimised the new authorities in the eyes of the population. The war persisted and the established regime had to rely on Russian power and the brutality of para-military Chechen troops (Ratelle and Souleimanov, 2016). The backbone of these troops relied on fighters who had defected and who proved their loyalty to the new regime by killing their former comrades-in-arms (Souleimanov, 2015) and forcing the civilian population of Chechnya into submission to the new government (Cornell, 2005; Ware, 2009). By and large, Akhmat Kadyrov up until his death was regarded by the population as 'Putin's puppet' (Traynor, 2004), although he retained or gained the support of some Chechens (Ratelle and Souleimanov, 2016). His assassination in 2004 did not derail the Chechenization policy. Rather, it only slightly interfered with Russia's reliance on the Kadyrov family as his only remaining son, Ramzan, was not yet of age to take over as official head of the republic. The interim presidency of Alu Alkhanov, who according to Souleimanov (2006) was regarded as 'a man of little importance', solved this problem. During the two-and-a-half years of his nominal presidency, the real power remained divided between Ramzan Kadyrov and a trustee delegated from Moscow who supervised the local authorities (Ratelle and Souleimanov, 2016). The balance of power shifted towards the Chechen appointees in 2005 when the last of the Moscow-delegated trustees, Sergei Abramov, resigned from his position as Chechnya's prime minister after a mysterious car accident. ${ }^{2}$

After his official appointment as president of the republic ${ }^{3}$ in 2007, Ramzan Kadyrov succeeded in building a 'sultanistic regime' with his very own cult of personality and unrestricted (even by Federal law) power (Dannreuther and March, 2008; Russell, 2008, 2009). His rise and success were made possible by the special relationship that prevailed between him and Putin. In exchange for the personal support of the Russian president and authority to govern with absolute power in the republic, Kadyrov ensures Chechnya's compliance with the Russian Federation (Russell, 20o9; 2011; Souleimanov, Abbasov, and Siroky, 2019; Wilhelmsen, 2018). Backed and supported by Putin, Kadyrov continues brutally and unlawfully to suppress any armed and political opposition

2 "Premier ministr Chechni Sergei Abramov podal v otstavku" (Prime-minister of Chechnya resigns), Lenta $R U, 28$ February 2006. https://lenta.ru/news/2006/o2/28/abramov/ (accessed 23 April 2021).

3 Since 2010, the president's title has been Head of the Republic in Chechnya. 
(Ware, 2009) and to eliminate potential competitors. During his rule - he has been reappointed twice since 2007 (and once directly elected) ${ }^{4}$ - methods of punishment and coercion such as torture, public humiliation, kidnapping, blackmail and ostracisation have become widely used in Chechnya (Cornell, 2005; Souleimanov, 2006; Sokiryanskaia, 2019). As Russell (2009) claims, by employing these methods, Kadyrov ensures that his personal power is the only source of state power in Chechnya. Undoubtedly, Kadyrov's brutality in suppressing local opponents is a response to the negative sentiment that a large part of Chechnya's population feels against him (Russell, 2009; Souleimanov and Siroky, 2016). It is difficult to quantify this claim, but it can be demonstrated through the numbers of followers of numerous opposition social media channels that operate in the republic and abroad. For example, the YouTube channel run by a popular blogger and ardent opponent of Kadyrov's regime, Tumso Abdurakhmanov (a.k.a Abu-Saddam Shishani) has more than 300,000 followers, the majority of whom are, most probably, Chechens. This is a substantial number for a nation of 1.5 million people. ${ }^{5}$

In addition to coercion, Kadyrov also relies on republican media resources to legitimate and consolidate his power. Through these media outlets, Kadyrov carefully portrays himself as a pious Muslim, religious leader and 'protector' of all Chechens both in and outside Chechnya (Russell, 2009; Falkowski, 2015, 18). Kadyrov's totalitarian control of the republic's media resources helps him to maintain this image. According to Falkowski $(2015,16)$, under the current regime, Chechnya's media is mainly engaged in promoting Chechen nationalism, reporting on Kadyrov's activities and advancing the cult of personality of both Kadyrovs.

It is important to note that some of his political decisions have enabled Kadyrov to gain genuine support among the general population of Chechnya and among Chechens abroad. As Souleimanov (2006) observes, Kadyrov's resolutions

aimed at stopping the "moral decline of the Chechen nation" (like the banning of slot machines and casinos as well as the fight against prostitution and alcoholism etc.) were especially popular with older Chechens,

4 In some meetings (usually with non-Chechen journalists), R. Kadyrov sometimes refers to this fact emphasising own legitimacy. He also reminds about the 2003 referendum (on the question of Chechnya's new constitution) claiming that it was a real choice of the Chechen nation.

5 According to the Federal State Statistic Service (https://rosstat.gov.ru/), the population of Chechnya in January 2021 numbered 1,500,46o. This data includes all ethnic groups (approximately $5 \%$ of the total) but does not take into account numerous Chechen communities in Russia and other countries, amounting to at least 30o,ooo people. 
while his political and financial success at a relatively young age and his influence have secured him a certain admiration among young people.

Despite this, however, Kadyrov's impunity coupled with outrageous violations of the law, his servile loyalty to Putin, his suppression of the Chechen population, and the way he flaunts his wealth - which contrasts with the impoverished majority of the population - undermines Kadyrov's efforts at self-legitimation (Russell, 2009; Souleimanov, Abbasov, and Siroky, 2019). Kadyrov understands that the orchestrated rallies of loyalty and support for the current regime do not represent the genuine feelings of the population. Therefore, in order to win hearts and minds and to legitimise his rule, he needs to reinforce domination by the use of other mechanisms, which will be identified in this study through the analysis of official discourse after the relevant theoretical and methodological foundations are presented.

This article's theoretical framework is composed of two components. The first presents the sources and discursive mechanisms that authoritarian regimes use to legitimise their rule. The second outlines the concept of discourse, which is necessary given the focus of the fieldwork.

To begin with, it is important to emphasise that a growing body of literature regards autocracies as political entities that, like democracies, need to legitimise their rule (Kailitz and Stockemer, 2017), on the basis that relying on repression alone is too costly to sustain a regime (Brady, 20o9; Gerschewski, 2013; Von Soest and Grauvogel, 2017). Therefore, autocracies also use discourse as a means to validate their claim to power and legitimise their rule by creating a positive image of themselves (Screti, 2013). The positive presentation of an autocratic regime as fair and good, as Alexander Dukalskis and Johannes Gerschewski (2017) suggest, contributes significantly to the regime's vitality.

To achieve this goal, authoritarian regimes use diverse discursive mechanisms of legitimation and refer to various sources of legitimacy. The choice of mechanism/s of legitimation and source/s of legitimacy depends on the type and strength of a regime as well as on its need to fend off a possible challenge (Howard and Roessler, 2006; Schedler, 2013, 78). Christian Von Soest and Julia Grauvogel (2017) listed six sources that authoritarian regimes refer to most often while claiming legitimacy: the foundational myth, ideology, personal qualities, electoral process, performance, and international engagement. The foundational myth implies a 'historical' presentation of a regime or its leader 
as indispensable to the state-building process (Beetham, 1991,103; Levitsky and Way, 2013; Schedler, 2013, 227). Depending on the population's views, ideology implies a reference to nationalism, religion or political/philosophical theories such as Liberalism or Communism (Krastev, 2011). Reference to personality is mostly related to the charisma of a leader (Brownlee, 2007) and, in some cases, the personality factor is bound to the stability and prosperity of the nation (Isaacs, 2010). The electoral process component is another source that authoritarian regimes increasingly turn to (Linz, 2000, 186) and the performance of the regime is one more important source of legitimacy; it is related to the regime's ability to satisfy people's economic, security or other needs (Dimitrov, 2009; Von Soest and Grauvogel, 2017. The last source, international involvement, refers to bolstering domestic legitimation efforts through international affairs or recognition received from other governments (Burnell, 2006).

Von Soest and Grauvogel (2017) claim that real-world cases are typically characterised by variations of these sources that resonate with the mechanisms of legitimation (see Table 1 below). Four such mechanisms have been identified by Dukalskis and Gerschewski (2017). The first, indoctrination, is mostly related to the foundational myth, ideology and leader's personality. Although successful indoctrination may not seem plausible today given the extent of technological progress and the population's access to multiple sources of information, authoritarian regimes have not completely discarded this mechanism. In contrast to the autocracies of the twentieth century, authoritarian regimes today attempt to indoctrinate their populations mostly without restricting people's access to alternative information. The second mechanism, passivity [of the population], is a goal of the authoritarian regimes that endeavour to make a population politically apathetic by using the means available to connect this 'mechanism' with all the listed above sources (Wedeen, 2015, 6).

TABLE 1 The interplay between mechanisms of de/legitimation and the corresponding sources of legitimacy that is observed in authoritarian political regimes.

Mechanisms Sources

Indoctrination $\quad$ Foundational myth; ideology; personality

Passivity $\quad$ Foundational myth; ideology; personality; process;

performance; international involvement

Performance Performance; international involvement

Process Process; international involvement

SOURCES: VON SOEST AND GRAUVOGEL (2017), DUKALSKIS AND GERSCHEWSKI (2017) 
The mechanism of performance (not to be confused with the source of legitimacy that has the same name) is directly related to the regime's success, or promise of it, in the spheres directly related to the population's need for stability, security and socio-economic well-being (Geddes and Zaller, 1989). Lastly, the mechanism of process mostly concerns regimes' electoral efforts of the regimes as well as the international recognition of elections (Gill, 2011; 2015; Kailitz, 2013).

The legitimacy sources and legitimation mechanisms are not always organised in the sets presented in Table 1 and the way they are combined may change depending on the individual case. For instance, the mechanism of indoctrination may, on some occasions, include elements of international involvement or even process, etc. Furthermore, these sets are not only used for legitimation purposes but also may be utilised to undermine opponents through delegitimising discourse. In order to invalidate their opponents' claims on power, regimes will refer to the indicated sources as a template with which to describe their political opponents as 'lacking legitimacy' (Steffek, 2003; Screti, 2013; Schleifer and Bloomfield, 2015). Oftentimes, the process of de-legitimation goes hand in hand with the process of self-legitimation, because a regime believes that the successful de-legitimation of an opponent increases its own legitimacy (Van Dijk, 2006).

Having outlined the sources of legitimacy and mechanisms for legitimation, we this article presents a framework for using another important research concept - discourse. Like many other concepts, discourse has a multitude of definitions of which each is constructed depending on the ontological and epistemological orientation, aim, focus and area of a study. This study's focus on the official discourse of authoritarian Chechnya limits the range of definitions to those that emphasise the nexus between discourse and power. Among them there is one presented by Shannon Fitzsimmons-Doolan (2009), who argues that discourse is a written or spoken text that amplifies beliefs and underlying ideologies. In their turn, Anthony Leow (2011) and Barbara Garrick (2011) claim that discourses represent the world, the vision and the values of policymakers, and that they shape ideology and power relations. Brianna Kennedy-Lewis (2014) and Alisa Leckie, Suzanne Kaplan, and Eliane Rubenstein-Ávila (2013) also highlight the ideological component of discourse and its ability to position and portray social actors, establish power relations, and reflect implicit power structures. Further, Anna Kilderry (2014) asserts that discourse is a form of social practice and institutionalised power that produces power relations and legitimises the authority and actions of the powerful. All these definitions emphasise that the importance of discourse lies in its ability to construct social reality or reproduce power (Parker, 2008) and, 
thus, to legitimise it. The focus of these definitions on discourse as text, as representations of ideology, or as the propaganda of the powerful, grounds discourse in the structuralist ontology that this article also follows. Furthermore, this study adopts a similar understanding of discourse and follows Jennifer Milliken's (1999) and Kate Anderson and Jessica Holloway's (2020) suggestion that it should be regarded in the same way as all forms of spoken or written, formal and informal, language or text, actions, narratives, and sets of beliefs and ways of seeing the world. This definition, without a claiming to be the only correct one, allows for an easy operationalisation. It includes not only discourse that is directly presented by officials but also discourse that is communicated indirectly, through journalists, and allows for a focusing of analysis on television programmes.

This article agrees with the idea that discourse is powerful enough not only to promote ideas but also to shape citizens' knowledge and to regulate their behaviour (Omelicheva, 2016). In other words, discourse is a powerful tool that authorities use to validate their right to rule in the eyes of the population. The success of this strategy to secure acceptance of authority, however, depends to a great extent on many variables that are mostly related to the quality of discourse and the population's dominant beliefs and convictions (Omelicheva, 2016). Having effectively excluded or discredited its opponents, over time the group in power can eventually modify the population's beliefs and validate its own visions (Tota, 2003), which has happened, for instance, in the Soviet Union (Markwick, 2001). In such cases, the population may eventually accept as legitimate a regime once deemed unacceptable.

To identify the mechanisms used by the Chechen authorities for selflegitimation, I use Critical Discourse Analysis (CDA), which is associated with the works of Norman Fairclough, Ruth Wodak and Teun Van Dijk. CDA unites a range of methods and techniques that target different aspects of discourse - its construction, its goals, and its connections with social and cultural processes and structures (Scollon, 1999; Rogers, 2004; Jeffries, 2007). CDA assumes that power relations are discursive, and that discourse is a form of social practice (Carvalho, 2008). As Norman Fairclough and Ruth Wodak (1997) argue, this implies a relationship between discourse and the situation(s), institution(s) and social structure(s) that frame it. This relationship makes CDA capable of not only identifying 'the author' of discourse but also of revealing the way in which power is imposed and put into practice (Van Dijk, 1993, 249-250; Machin 
and Mayr, 2012: 4;). The main interest of CDA is to explore hidden, opaque, and visible structures of dominance, discrimination, power and control' (Wodak and Meyer, 2016: ). In addition to analysing discourse, CDA explains how structures of dominance are sustained by putting them into a historical-political context (Wodak and Meyer, 2016).

This brief description of CDA's capability and its focus demonstrate its suitability for highlighting the 'implicit or indirect meanings' of official discourse (Van Dijk, 2001), which is the goal of this article. Instead of focusing on hidden ideologies, which CDA scholars usually aim to 'draw out' from discourse (Machin and Mayr, 2012, 25; see also Van Dijk, 2006), this research unveils the legitimation mechanisms of discourse. Just like ideologies, legitimation mechanisms are concealed in the texts, advertisements, political speeches and textbooks that construct social reality in favour of the powerful (Zajda and Zajda 2003; Pennebaker, Rim, and Paez, 2013: $\mathrm{x}$ ).

The decision to use CDA in this article was also determined by the methodology's flexibility. CDA allows researchers to develop their own analytical strategies, depending on the research question and the type of materials at hand (Jäger and Maier, 2016; Wood and Kroger, 2000: 26). CDA does not restrict researchers in regard to units of analysis either. They may range from words, phrases, and sentences to paragraphs, texts, conversations, speeches, or communicative events (Wodak and Meyer, 2016; Wood and Kroger, 200o: 28). Therefore, as Greg Philo (2007) suggests, CDA can be used to identify the major themes of discourse and even to project what hides beyond (e.g. legitimation mechanisms).

As suggested by the founding fathers of CDA (Van Dijk, 1993; Fairclough and Wodak, 1997), this article uses CDA to investigate the ways in which the regime and leader of Chechnya are presented on Grozny TV. It analyses various events that it broadcast, including the speeches, actions and behaviour of Chechnya's politicians; the journalistic presentation of the regime; and the content of the targeted programmes. It also utilises the multimodality of CDA (Machin and Mayr, 2012: 6) to analyse the images, music and layout. Finally, as Elfriede Fürsich (2009) recommends, it extends the application of CDA by situating the investigation in the historical-political context in which the discourse is produced. The focus of this study on Chechen state television programmes excludes some aspects of Chechen official discourse that are communicated through other channels, such as books, newspapers, educational institutions and policy papers, etc. This is a deliberate choice that allows for some parts of the official discourse to be examined in further research.

To analyse official Chechen discourse, this article mainly focuses on two programmes on Grozny TV - 'News' and 'Illusion'. The study also refers to a political advertisement, which was regularly shown on television as part 
of the 'News' programme. The analysis also benefits from consideration of some other documentaries and footage that were also broadcast by Grozny TV, including the 'documentary' released about Akhmat Kadyrov's life titled 'Sviet bez teni' ('Light without shadow' - Russian) - a direct allusion to a person's angelic nature. ${ }^{6}$ In addition, to support its argument, the article brings in older news materials as well as those observed after fieldwork was completed. Nevertheless, the study maintains its focus on the 'News' programme broadcast during winter-spring of 2018 and the political-historical programme 'Illusion'.

Both the programmes analysed were selected as most suitable for the aims of this research after a rigorous review of the content of Grozny TV. The 'News' programme is broadcast several times a day with the most extensive content being presented in the evening. I therefore watched the evening news, broadcast at $10 \mathrm{pm}$ local time, as part of this study. The 'News' programme was chosen for this analysis because of its main function - not merely to inform the population, but also to create a positive image of the regime and its leader as well as to convey the authorities' messages to the population. I came to this conclusion after calculating the amount of time the news programme usually dedicated to reporting on Ramzan Kadyrov, his family and his daily schedule. Such reports would usually take up about $50 \%$ to $90 \%$ of the programme, with Kadyrov on screen for an average of $10 \%$ to $40 \%$ of the total time. This function of the Grozny TV 'News' programme is the basis for regarding it as an outlet for communicating the official discourse.

To identify the mechanisms of legitimation exercised in the Chechen Republic, I watched this programme every day from 1 January to 1 June 2018. During the last month (May 2018) of, it became clear that dramatic changes in the themes or topics presented by the 'News' programme were highly unlikely, so I stopped collecting data and proceeded to categorise it. The additional segments of the programme that I watched after collecting the bulk of my data, from June 2018 to August 2020, corroborated my conclusion regarding the improbability of change with regard to its topics and themes. This article refers to these later segments of 'News' too as they confirm the limited thematic content of the Grozny TV.

Regular observation of the 'News' programme shows that it covers a number of distinct themes: politics, security, religion, economics, (re)construction, war, tourism, celebration, folklore, honouring the memory of Akhmat Kadyrov, leisure of the Chechen president and his family, R. Kadyrov's daily activities. Most of these topics can be classified under the two main categories of security and religion, which are communicated through the speeches of R. Kadyrovas

6 'Light without Shadow'. https://www.youtube.com/watch?v=C61qz6d_9Ns (accessed 24 March 2018). 
well as his associates and the 'News' reports. With this in mind, this article proposes that the major identified themes - security and religion - be analysed against the mechanisms and sources of legitimation presented in Table 1.

In addition to the 'News' programme, other Grozny TV programmes also serve to bolster the regime's claims to legitimacy. An analysis of the content of the Chechen state television makes it possible to categorise it under several heading, some of which coincide with the identified thematic categories of the 'News' programme. For instance, there are religious and historicalpolitical programmes that are broadcast every day on Grozny TV. I identified the historical-political program 'Illusion' as the most relevant for this research because it aims to directly create and communicate the official vision of recent Chechen history (1991-1999), which is one of the topics most often referred to in the speeches of the Chechen elite today. The programme is also constructed around the two main themes of official Chechen discourse, security and religion, which were also identified through the analysis of the 'News' programme. In total, 40 episodes of 'Illusion' were released by Chechen state television. Some of those I watched were previous episodes only available via the Internet, ${ }^{7}$ while others were being aired for the first time. Because the programme went out during prime time, I deduced that it reached the largest possible audience and these broadcasts were of great importance to the government. The political overtones, engagement and presentation of this programme in the recent past were positively assessed by the Chechen regime and the show's creator, Chingiz Akhmadov, was rewarded by being appointed as director of Grozny TV in June 2020. ${ }^{8}$

\section{$5 \quad$ Indoctrination through De-legitimation}

The first theme that stands out to a 'News' programme viewer, because it is constantly featured, is that of de facto independent Chechnya (1991-1994 and 1996-1999). The discourse surrounding this topic compares a 'negative' past with the 'positive' present, and this invitation to contrast the two is one of the government's self-legitimation strategies. Indeed, the Chechen authorities, as is common in many autocracies (Schudson, 2011), criticise the past (previous

7 Due to the changed design of the Grozny TV website, past episodes of 'News' and 'Illusion' are no longer available through Internet links.

8 "Nagrada za slova: karyera propagandista Akhmadova" (The reward for the words: the career of propagandist Akhmatov - Russian). https://www.kavkaz-uzel.eu/articles/ $351324 /$ (accessed 1 September 2020). 
governance) to legitimise the present (current rule). The critique of Chechen secessionist rule (1991-1994 and 1996-1999) starts by presenting it as an existential threat to the whole Chechen nation. Moreover, according to the official discourse, this regime also threatened the stability of the whole Russian Federation and even put security at risk on the international level. The official discourse pertaining to this period focuses mostly on the presidencies of Dzhokhar Dudayev (1991-1996) and then of Aslan Maskhadov (effective in 1997-1999). The short period from the end of the first Russo-Chechen war in 1996 up until the presidential elections of 1997, which includes the interim presidency of Zelimkhan Yandarbiev, is usually omitted from the official discourse.

The current Chechen government's version of history describes Dudayev's regime as both criminal and corrupt and as responsible for inciting anarchy in the republic. According to the official discourse, Dudayev's regime created the environment for a reign of lawlessness in Chechnya. It also claims that, under Dudayev, the government was merged with the criminal underworld and participated in its illegal activities, which included 'trade on the global oil and weapon markets. ${ }^{9}$ This business, according to the discourse, left the government no time for state-building, which led to a collapsing economy, deteriorating social security and a rise in everyday criminality within the republic.

Russia during this period is also painted negatively by the official Chechen interpretation of history, which depicts the Russian political elite as accomplices of Dudayev and his administration's criminal activities. ${ }^{10}$ By including criticism towards Russia, the official Chechen interpretation of history, most likely, attempts to establish a legitimacy in its assessments, which is suggested to be extrapolated to the evaluations of historical-political events in Chechnya.

Russia's defeat in 1996 and the subsequent Russo-Chechen (Khasavyurt) Peace Accords paved the way for democratic elections in Chechnya as well as Aslan Maskhadov's rise to power in 1997. Maskhadov's rule, according to official statements, turned Chechnya into a failed state. The official Chechen discourse claims that his government was too weak to control the territory effectively because Chechnya was divided among influential warlords, and many were gradually falling under the influence of so-called 'Wahhabis' adherents of Salafi Islam who were often portrayed as terrorists within Russian political discourse (Wilhelmsen 2016, 69-84). The inability or unwillingness of Maskhadov's government to 'remove' the Wahhabis from the Republic, according to the official discourse, turned Chechnya into one of 'the world centres of grozny.tv/peredachi.php?catid=188\&id=33924 (accessed 13 October 2018). 
international terrorism.. ${ }^{11}$ Adding to the validity of this claim, Chechen officials recall that the Wahhabis established 'terrorist training-centres' in the republic and also refer to the Wahhabi-led incursion into Dagestan in 1999 that started the second Russo-Chechen war. Official discourse asserts that Maskhadov supported all the Wahhabis' activities and thus 'breached the Peace Treaty between Chechnya and Russia signed by himself and Russian president Boris Yeltsin in 1997'. This 'disrespect for the Treaty' is interpreted by the official discourse as 'a criminal act from the points of view of both secular and Islamic law'. ${ }^{2}$

To sum up, today's official Chechen discourse, in an attempt to indoctrinate the population, tries to delegitimise the former Chechen de facto independence by criticising its leaders' performance and personalities. This discourse largely ignores sources that assert the former regime's legitimacy through ideology (nationalism-based search for independence), process (internationally recognized democratic elections), and attempts to engage in foreign affairs (Williams, 2000; Hughes, 2001; Bowker, 2004). The de-legitimation discourse also refers to the previously identified themes of official discourse (security and religion) and suggests that the period should be remembered as a 'time of darkness and chaos'. Chechen state television often depicts this as an anarchic, lawless and unstable time when anyone could 'buy guns at the bus stop', 'public executions became a routine' and 'criminals were ruling the republic.'. ${ }^{13}$ This discourse is usually accompanied by ominous sounding music and some unclear footage, inviting the viewer to see a stark contrast with the current government's 'safety and stability'. This indoctrination strategy is similar to those used by totalitarian regimes and described by Hannah Arendt ([1951] 1966, 470), which are not based on empirical reality but such regimes nevertheless claim absolute knowledge (including of the past), and mobilise the media for their own purposes. Using this strategy, Chechen officials create a background for the foundational myth that legitimises the present regime, which started with the appointment of Akhmat Kadyrov as Head of the Chechen Administration in 2000.

\footnotetext{
11 'Illusion', 22 July 2017 (Aslan Maskhadov). https://grozny.tv/peredachi.php?catid= 188\&id=32505 (accessed 15 April 2018).

12 Ramzan Kadyrov on 'News', 17 April 2018. https://grozny.tv/peredachi.php?catid= 148\&id=33210 (accessed 15 September 2018).

13 'Illusion', 24 September 2017 (Dzhokhar Dudayev). https://grozny.tv/peredachi.php? catid=188\&id=32510 (accessed 17 September 2018.
} 


\section{Legitimation of the Present}

Official Chechen discourse presents Akhmat Kadyrov's tenure as critical for the survival of the Chechen nation. The Chechen state television, republican authorities and public figures portray him as someone who tackled an unruly situation, brought Chechen territory under the government's (Russian and Chechen) control, put an end to the crimes of the Russian military, created the conditions for peace in the republic, and 'saved' the Chechen people from (or alternatively 'defeated')] international terrorists. ${ }^{14}$

Akhmat Kadyrov's role is remembered in every public speech made by officials, and this became a format or an example to be followed by randomly interviewed individuals. His memory is immortalised through his numerous portraits both outside and inside public offices, through books and films about him, memorials and museums, places named after him such as the central mosque, the Olympic stadium in Grozny, a 435-metre tower (under construction), various streets, and even the Chechen football club. Furthermore, the slogan 'Akhmat sila' (Russian for 'Akhmat power'), shouted three times, mimicking the way that the phrase 'Allahu akbar' (Arabic for 'God is great') was shouted in Chechnya during the 1990s, has become the republic's official rallying cry. Today, this phrase adorns the roof of Grozny airport, greeting arrivals and seeing off departures.

In brief, the official Chechen discourse suggests that Akhmat Kadyrov should be remembered as the father of the nation who showed his people 'the way', as 'the Hero of Russia and the first president of the Chechen Republic' who 'left us undefeated', and as one whose name must be spoken with veneration. The most important of his achievements, official discourse suggests, is that he through referendum of 2003 'put Chechnya on the rails of peace' and outlined the principles that the nation must adhere to in order to become peaceful and prosperous within the Russian Federation. Further, the discourse proposes that these principles be remembered as they were decisive in the 'success that Chechnya has already achieved today' under the leadership of his son and follower Ramzan ('Light without Shadow', 24 March 2018).

Even though Chechnya is not an independent state, the representation of A. Kadyrov, which official discourse presents, demonstrates all the attributes of the foundational myth, as described by Von Soest and Grauvogel (2017). This foundational myth aims to instill in the population a political passivity and promote for or at least acceptance of the regime by referring to the themes

14 'Light without Shadow'. https://www.youtube.com/watch?v=C61qz6d_9Ns (accessed 24 March 2018). 
of security (bringing peace to the republic) and religion (defeating Salafists/ international terrorists). Furthermore, the claim that Akhmat Kadyrov was a saviour - a central figure in the nation-building process, provides the background for the legitimation of his son, who still rules the republic today. Further analysis uncovers other components of the discursive legitimation of Chechnya's current ruler and generally rotates around the same two identified themes, security and religion.

\section{$7 \quad$ Security}

The brutal suppression of the armed groups and non-violent political opposition, which brought the current Chechen regime to power (Souleimanov, 2015), naturally calls the authorities' attention to questions of 'safety and security', whose importance lies not only in removing a domestic political and violent opposition but also in ensuring further support from Moscow. As many researchers have noted, the current Chechen government gained this support in exchange for its declaration of loyalty to Russia and peace in the republic (Russell, 2009; Ware, 2009). All security issues in Chechnya are therefore dealt with at the highest political level and as quickly as possible. For instance, during an attack on an Orthodox church in Grozny in May 2018, the entire political leadership (with Ramzan Kadyrov himself controlling the anti-terrorist operation) was near the site of the incident and the whole operation was over in less than an hour. ${ }^{15}$

The official Chechen discourse depicts security issues as of existential importance for the nation's survival and handles them in a manner that paints the regime as one that 'fights international terrorism' and endeavours to 'protect the nation, peace, stability, and justice.'16 This journalist's report also reminds the population that the republic's peace and security only became possible 'thanks to the efforts of Ramzan Kadyrov and his government'. Besides casting all armed and peaceful opposition, as 'international terrorism', the discourse, in order to emphasise its truthfulness and gain more public support, sometimes also reminds the public that the current regime 'stopped the Russian military machine that terrorised the civilian population'. ${ }^{17}$ To bolster the regime's achievements in this field, the official discourse often states that

\footnotetext{
15 'News', 19 May 2018. https://grozny.tv/peredachi.php?catid=148\&id=33316 (accessed 19 May 2018).

16 'News', 27 April 2018. https://grozny.tv/peredachi.php?catid=148\&id=33248 (accessed 27 April 2018).

17 Ibid.
} 
Chechnya 'is rightly considered to be the safest region in Russia'. In journalistic reports, this statement is usually supported by footage of the streets of Grozny full of people at night (a major change from the times of de facto independent Chechnya, when life on the streets would 'die' at sunset). Ramzan Kadyrov himself is actively involved in the promotion of the image of safety in the republic. In a series of self-made video reports, each of which take up to $50 \%$ of a 'News' broadcast, Kadyrov strolls around Grozny at night 'without bodyguards but with his friends and associates'. The 'mobile reporter', as he calls himself, emphasises the regime's achievements in the field of security: 'It is already midnight, but there are people outside...', 'look at these white Rolls-Royces parked right here [without extra protection] ... just like in Dubai, isn't it cool? What a beauty! Masha Allah [an Arabic exclamation of thankful appreciation]!."18 The image of 'safety' is also promoted by reports regarding the growth of tourism in Chechnya. The discourse regarding 'the prosperity that Chechnya enjoys' ${ }^{19}$ further reinforces legitimation efforts.

\subsection{Economy and Construction}

The themes of economic growth and construction are set out to boost the government's security discourse. By constantly boasting about economic growth, the regime emphasises that it would be impossible to achieve this prosperity without the necessary security achieved in the republic.

The most significant proof of the republic's wealth and the government's success in providing it is the rebuilt capital of Chechnya - Grozny. 'No one could believe that it was possible to do so [rebuild the city] in such a short time, but Ramzan Kadyrov and his team managed to do the unbelievable', asserts Grozny TV. ${ }^{20}$ This journalistic appreciation of the administration's work is usually backed up with images of Grozny's shining buildings: new skyscrapers, shopping malls, zoos, theme parks, children's playgrounds, sports clubs, recreation centres, spas, and even a sound and light fountain off the shore of the Grozny Sea. All of this became possible, according to the Chechen state television, through the hard work of Kadyrov, to whom people should be immensely grateful - and they apparently are, as demonstrated by a slogan written in huge letters on the slope of a hill in the capital's Chernorech'e district: 'Ramzan spasibo za Grozny' (Russian for 'Ramzan - thanks for Grozny').

18 Ibid.

19 Ibid.

20 'Big Construction', 16 September 2019 (a documentary about the reconstruction of the Chechen Republic). https://www.youtube.com/watch?v=lMW_pCAojYc (accessed 16 September 2019). 


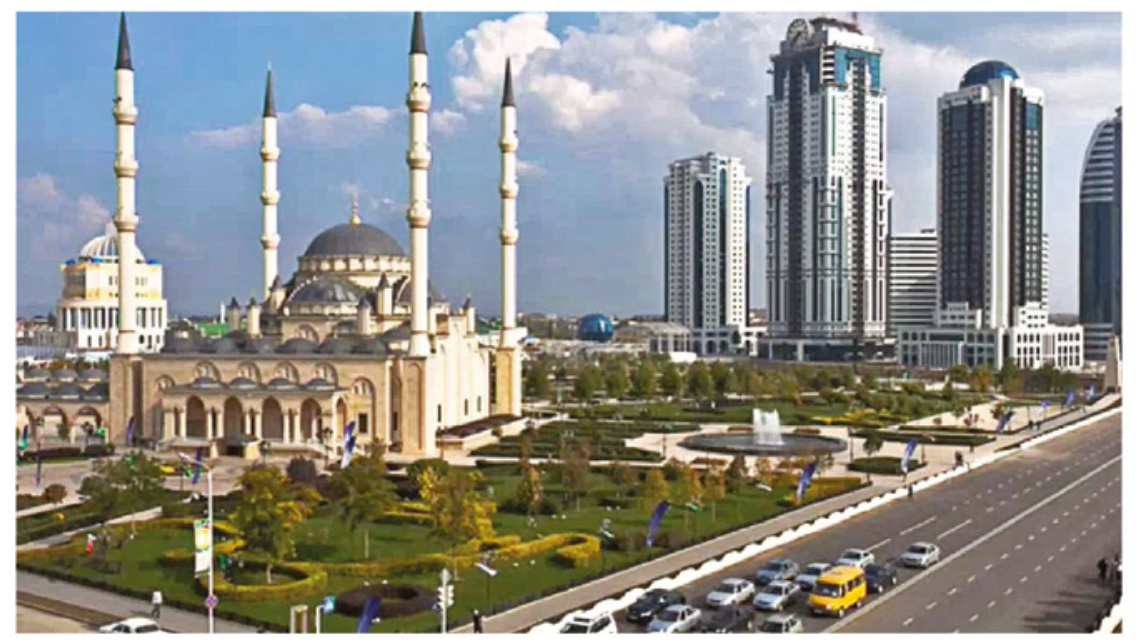

FIG URE 2 Grozny's shiny buildings are the pride of the current administration AUTHOR'S PERSONAL PHOTO

The discourse about Kadyrov's efforts in this field extends far beyond the capital. In the spring of 2018, the 'construction project of the century' in the town of Shali became the main focus of the 'News' programme. Reports showed not only the 'new tourist centre' but also the 'happy inhabitants' who were forced from their houses to provide the land used for the construction. ${ }^{21}$

The post-war reconstruction of the republic's industrial sector also adds to this theme and Chechen television sells these modest developments as huge achievements. Examples include the new technological centre 'Kazbek', which aims to 'supply the whole North Caucasus with construction materials';22 or the assembly of the 'new and unique' multifunctional buggy type car named Cha-Borz (Chechen for Wolf-bear), which 'will satisfy the demands of the Russian army, tourism and export'.23

In sum, the security theme is mainly utilised to build up and inflate accompanying sources of legitimation such as personality and performance. Discourse that employs the security theme emphasises the success of the government and Kadyrov personally in tackling security issues, reconstructing the republic, improving economic capacity and ensuring the population's security.

21 'News', 7 May 2018. https://grozny.tv/peredachi.php?catid=148\&id=33280 (accessed 7 May 2018).

22 'News', 2 May 2018. https://grozny.tv/peredachi.php?catid=148\&id=33267 (accessed 2 May 2018).

23 Ibid. 
The theme of religion also occupies a significant part of the official discourse that this article examines and is critical to the self-legitimisation efforts of the Chechen government for two reasons. First, religion is the basis for one of the two main collective identities (religious and ethnic) of the Chechen people (Hertog, 2005). These identities sometimes compete and sometimes complement each other. Second, religion is directly related to questions of security as the final years of the Russo-Chechen conflict were marked by religious undertones (Russell, 2008; Souleimanov and Ditrych, 2008; Schaefer, 2010; Yemelianova 2014). Thus, by exploiting the religious theme, the Chechen authorities try to emphasise their devotion to the nation and, at the same time, remove the justification for armed resistance.

Indeed, official Chechen discourse carefully portrays and frequently recalls that Ramzan Kadyrov is a pious Muslim. For instance, one Grozny TV report broadcast in May 2018 was dedicated to a gathering in 'the house of Kadyrov's mother Aymani. ${ }^{24}$ The republic's prominent 'theologians and believers celebrated one of the significant nights in Islam by reciting Mawlid [verses written for the celebration of the Prophet Muhammad's birthday] there'. The report showed the leader of Chechnya, together with the mufti of the republic and other religious figures, praying and reciting verses from the Qur'an. The report emphasised that Ramzan Kadyrov's sons also always participated in this kind of gatherings from a very early age. ${ }^{25}$

The religious theme also contribute to legitimation by adding an international perspective (one of the legitimacy sources). Besides the public reactions to the Islamist attacks on the Charlie Hebdo office and the persecution of Rohingya Muslims, Kadyrov regularly visits the Middle East and promotes himself in the Islamic world through charitable acts such as 'providing Iftar [the evening meal after a day of fasting in Ramadan] for one million Muslims in Syria, ${ }^{26}$ distributing clothes, food and water to internally displaced Syrians, and supporting the children of Rohingya refugees, ${ }^{27}$ and so on.

In addition to burnishing his 'Islamic' image through numerous reports, Kadyrov himself often speaks about the revival of Islam that 'happened under

\footnotetext{
24 'News', 1 May 2018. https://grozny.tv/peredachi.php?catid=148\&id=33266 (accessed 1 May 2018).

25 Ibid.

26 'News', 29 August 2018. https://www.youtube.com/watch?v=BZktxa3kaAw (accessed 20 September 2019).

27 'News', 3 June 2018. https://www.youtube.com/watch?v=dz845s9ZYrk (accessed 20 September 2019).
} 
his rule'. Coupled with the critique of de facto independent Chechnya, when 'not even one new mosque was built in the Republic', this image stands in opposition to claims that there is no religious freedom in Chechnya. ${ }^{28}$

\subsection{Ethnic Identity}

Legitimation through religion is reinforced by the presentation of the Chechen government as one that fosters ethnic identity. Both collective identities (religious and ethnic) are so intertwined in the Chechen consciousness that people have difficulty understanding where one identity ends and the other begins. Religion undoubtedly contributed to the survival of the nation during the period of deportations and exile in 1944-1957 (Bedford and Souleimanov, 2016) and helped to maintain and promote the basics of ethnic identity such as patriarchal family structure, traditions and language. Indeed, in the Soviet Union, the Chechens were considered one of the least assimilated nations. Close to $100 \%$ of people of Chechen origin would claim their belonging to their nation and well over $9 \circ \%$ would state that Chechen is their first language (Dostál and Knippenberg, 1992; Gorenburg, 2006). The salience of Chechen ethnic identity certainly grew even more as a result of the dissolution of the Soviet Union in 1991 and the consequent Russo-Chechen wars, and so the dismissal of this theme would weaken the chances of the Chechen administration being recognized as 'the true people's government'. The official Chechen discourse demonstrates its focus on ethnic values in many ways. In his speeches, Kadyrov has regularly stated that 'he will not allow the tarnishing [of] Chechen traditions. ${ }^{29}$ This kind of pompous statement would usually be broadcast in response to 'immoral' behaviour on the part of an individual of Chechen origin. For instance, in 2014, Kadyrov's reaction was provoked by a video of an unmarried couple (circulated in social media) that concluded a Chechen folk dance with uncustomary and intimate embraces. In 2019, the object of official public reprimand was a man who, contrary to Chechen tradition, was filmed near his daughter in a wedding dress, just before letting her go with the groom's party who had arrived. This kind of 'disrespect' for Chechen traditions was punished by the man's public humiliation and the demand that he record a video apology addressed to 'the whole Chechen nation' and Kadyrov personally.

Another way that the government demonstrates its devotion to Chechen ethnic identity is through the popularisation of the Chechen language.

28 'News', 1 May 2018. https://grozny.tv/peredachi.php?catid=148\&id=33266 (accessed 1 May 2018).

29 'News', 25 September 2019. https://www.youtube.com/watch?v=_tO43bieLTE\&list=PL7 WqabJLxZGwjtkURBRoJO1xGzVXs4cCo\&index=40o (accessed 3o September 2019). 
Chechen state television allocated prime time to cover preparations for the celebration of Chechen Language Day on 25 April 2018. For the entire week before the celebration, there were regular broadcasts of the 'poetry competition' initiated by Khamzat Dudayev, who was the Grozny TV director at the time. To support Chechen Language Day, Dudayev challenged every official to read pieces of poetry in Chechen during that week. Kadyrov's reading of Chechen poetry on horseback, clad in Chechen folk dress, was imitated by other politicians..$^{30}$ On the day of the celebration (25 April), Kadyrov and his associates appeared in the festival square wearing Chechen folk costume and even ancient Chechen armour. ${ }^{31}$ In general, the promotion of Chechen language and culture aims to motivate the population to appreciate the efforts of the government, which 'guaranteed [the population] the right to speak their language and practise traditions' - which was not assured during the Soviet times.

To sum up, the conflation of two collective identities, as seen by the intertwining of the themes of religion and ethnicity, is crucial in the discursive legitimation strategy of the current Chechen regime. By merging and utilising these themes, the government reinforces sources of legitimation such as personality and performance by creating an image of Kadyrov as a truly religious and nationalistic leader of the Chechen people.

\section{9}

\section{Conclusion}

The eight-minute-long political advertisement regularly shown after the evening news summarises the content of the day's official Chechen discourse. It introduces five 'random' people whose individual discourse delegitimises the past and legitimises the present by referring to sources such as personality, ideology, performance and the foundational myth. The advertisement begins by presenting a schoolboy, who says that he likes his beautiful shiny city [Grozny] and that he has many friends there, including 'the friend of all children Ramzan Kadyrov'. His de-legitimation of the terrifying past is demonstrated in his discourse about the time 'when even kids used to die', which he had learned from his mother as he is too young to remember it. The advertisement moves on to a policeman, who describes the horrible past from the

30 'News', 18 April 2018. https://grozny.tv/peredachi.php?catid=148\&id=33221 (accessed 18 April 2018).

31 'News', 25 April 2018. https://grozny.tv/peredachi.php?catid=148\&id=33242 (accessed 25 April 2018). 
perspective of an adult who 'defended the city' or [at least] 'fought trying to protect it from international terrorism', which was successfully defeated, and order was eventually re-established in the republic. Next, the advertisement moves on to the narrative of a construction worker. He shares his memories about the ruined Grozny and his work rebuilding it. A schoolteacher then talks about her students. She is proud that they have become useful members of society and contribute to the current prosperity of Chechnya. The last narrative comes from an actor, who was very lucky to know the one who departed invincible' (a metaphor alluding to Akhmat Kadyrov). The advert ends with an appreciation of Ramzan Kadyrov's work in rebuilding the city and his efforts to follow the 'way of his father - the only right way for the nation'.

This advertisement corroborates this article's thesis by referring to four of the main sources of legitimacy (ideology, performance, personality and foundational myth) and it also helps to indoctrinate the population by promoting the current regime. Similarly to the 'Illusion' programme, the advertisement aims to delegitimise the past along with the political alternative. Unlike the 'News' programme, however, neither 'Illusion' nor the advertisement use the mechanism of performance (see Table 2 below) because of the limitations of their format.

TABLE 2 The television programmes analysed in this article that the Chechen regime uses for self-legitimation purposes with regard to mechanisms of de/legitimation and sources of legitimacy

\begin{tabular}{|c|c|c|c|}
\hline Themes & $\begin{array}{l}\text { Television programmes } \\
\text { for de/legitimation }\end{array}$ & $\begin{array}{l}\text { Mechanisms of } \\
\text { de/legitimation }\end{array}$ & $\begin{array}{l}\text { Sources } \\
\text { of legitimacy }\end{array}$ \\
\hline \multirow[t]{4}{*}{ Security } & 'News' & Indoctrination & $\begin{array}{l}\text { Foundational myth, } \\
\text { ideology, personality, } \\
\text { performance }\end{array}$ \\
\hline & & Performance & $\begin{array}{l}\text { Performance, } \\
\text { international } \\
\text { involvement }\end{array}$ \\
\hline & 'llusion', documentary & Indoctrination & $\begin{array}{l}\text { Foundational myth, } \\
\text { ideology, personality, } \\
\text { performance, } \\
\text { international } \\
\text { involvement }\end{array}$ \\
\hline & Advertisement & Indoctrination & $\begin{array}{l}\text { Foundational myth, } \\
\text { ideology, personality, } \\
\text { performance }\end{array}$ \\
\hline
\end{tabular}


TABLE 2 The television programmes analysed in this article (cont.)

\begin{tabular}{|c|c|c|c|}
\hline Themes & $\begin{array}{l}\text { Television programmes } \\
\text { for de/legitimation }\end{array}$ & $\begin{array}{l}\text { Mechanisms of } \\
\text { de/legitimation }\end{array}$ & $\begin{array}{l}\text { Sources } \\
\text { of legitimacy }\end{array}$ \\
\hline \multirow[t]{4}{*}{ Religion } & 'News' & Indoctrination & $\begin{array}{l}\text { Foundational myth, } \\
\text { ideology, personality, } \\
\text { performance, } \\
\text { international } \\
\text { involvement }\end{array}$ \\
\hline & & Performance & $\begin{array}{l}\text { Performance, } \\
\text { international } \\
\text { involvement }\end{array}$ \\
\hline & 'Illusion', documentary & Indoctrination & $\begin{array}{l}\text { Foundational myth, } \\
\text { ideology, personality, } \\
\text { performance }\end{array}$ \\
\hline & Advertisement & Indoctrination & $\begin{array}{l}\text { Foundational myth, } \\
\text { ideology, personality, } \\
\text { performance }\end{array}$ \\
\hline
\end{tabular}

All of the television programmes analysed are actively used by the Chechen government for self-legitimation as well as for the de-legitimation of the political alternative, which is de facto independent Chechnya. All the programmes refer to the specified sources of legitimacy and use the mechanisms indicated, which aim to ensure the population's acceptance of, support for, or political indifference/passivity towards the current regime. At the same time, by operating the same mechanisms and referring to the same sources, the programmes try to depict the previous regime as lacking legitimacy.

As this study demonstrates, official Chechen discourse mostly refers to five out of six legitimacy sources (the almost excluded element is electoral process) and weaves together three of the four cited legitimation mechanisms. The discursive strategy of the Chechen authorities identified through the 'News' and 'Illusion' programmes Grozny TV mostly employs the mechanisms of indoctrination and performance but also aims to bring about the population's indifference, if not its support of the regime. Both legitimation and delegitimation processes build a base for creating the foundational myth about the salvation of the nation from the threat of international terrorism by of the founder of the current regime, Akhmat Kadyrov, and his son. The myth of 'Akhmat Kadyrov's path', created by the current government, has become a new ideology for Chechnya, which is supported by the populist activities that 
promote ethnic nationalism and religion. The regime's reference to the two most salient Chechen collective identities is intended to balance out the government's own origins and loyalty to the Russian state, which fought two wars against the Chechens in the past three decades.

The discourse that this article has examined supports the indoctrination of the population by the mechanism of performance. This mechanism includes the factor of a leader's personality, as seen in the promotion of Ramzan Kadyrov's ability to achieve what 'others cannot' in the field of construction and in improving the nation's wealth. In addition, his personal contacts with leaders of Muslim countries and his foreign visits (even if limited to the Middle East) contribute to the legitimation of the government by projecting extensive international involvement, demonstrated by the way he is given an official reception in other states. However, the most important of the leader's achievements is the republic's security. This theme prompts legitimation not only on the domestic level (through the foundational myth) but also on the federal level. In other words, besides being the provider of the population's safety, the current government is a guarantor of stability in the eyes of the Russian government. This status ensures constant support from Moscow, which remains the decisive factor in the regime's longevity.

The appointment of the Chechen ruler by Moscow renders the mechanism of process irrelevant for analysis, whereas the mechanism of passivity continues to be the goal of the government, as security concerns are still of the utmost priority. The article avoids assessing or measuring the success of official Chechen discourse, which will be the task of further research.

\section{Acknowledgements}

The author is grateful to all colleagues, who read and commented on the early versions of this article. The gratitude is extended to two anonymous reviewers and, the biggest thanks goes to Nicole Moshel, who proofread this article.

\section{References}

Anderson, Kate T., and Holloway, Jessica, "Discourse analysis as theory, method, and epistemology in studies of education policy", Journal of Education Policy 35/2 (2020), 188-221.

Arendt, Hannah, The Origins of Totalitarianism (San Diego: Harvest, 1966 [first published 1951]). 
Bedford, Sofie, and Souleimanov, Emil Aslan, "Under construction and highly contested: Islam in the post-Soviet Caucasus", Third World Quarterly 37/9 (2016), 1559-80.

Beetham, David, The Legitimation of Power (London: McMillan, 1991).

Bowker, Mike. "Russia and Chechnya: the issue of secession." Nations and Nationalism 10, no. 4 (2004): 461-478.Brady, Anne-Marie, "Mass persuasion as a means of legitimation and China's popular authoritarianism”, American Behavioral Scientist 53/3 (2009), 434-57.

Brownlee, Jason, "Hereditary succession in modern autocracies", World Politics 59/4 (2007), 595-628.

Burnell, Peter, "Autocratic opening to democracy: Why legitimacy matters", Third World Quarterly 27/4 (2006), 545-62.

Carvalho, Anabela, "edia (ted) discourse and society: Rethinking the framework of critical discourse analysis", Journalism Studies 9/2 (2008), 161-77.

Cornell, Svante E., "A virtual election in a fantasy Chechnya", TheMoscowTimes.com, 21 December 2005.

Dannreuther, Roland, and March, Luke, “Chechnya: Has Moscow won?" Survival 5o/4 (2008), 97-112.

Dimitrov, Martin K., "Debating the color revolutions: Popular autocrats", Journal of Democracy 20/ (2009), 78-81.

Dostál, Petr F., and Knippenberg, Hans, "Russification of Soviet nationalities: The importance of territorial autonomy", History of European Ideas 15/4-6 (1992), 631-8.

Dukalskis, Alexander, and Gerschewski, Johannes, "What autocracies say (and what citizens hear): Proposing four mechanisms of autocratic legitimation", Contemporary Politics 23/3 (2017), 251-68.

Fairclough, Norman, and Wodak, Ruth, "Critical discourse analysis", in Discourse Studies: A Multidisciplinary Introduction, Teun Van Dijk (ed.) (London: Sage, 1997), 357-78.

Falkowski, Maciej, Ramzanistan: Russia's Chechen Problem (Warsaw: Ośrodek Studiów Wschodnich im. Marka Karpia, 2015).

Fitzsimmons-Doolan, Shannon, "Is public discourse about language policy really public discourse about immigration? A corpus-based study", Language Policy 8/4 (2009), 377-402.

Fürsich, Elfriede, "In defense of textual analysis: Restoring a challenged method for journalism and media studies", Journalism Studies 10/2 (2009), 238-52.

Garrick, Barbara, "The crisis discourse of a wicked policy problem: Vocational skills training in Australia", Australian Educational Researcher 38/4 (2011), 401-16.

Geddes, Barbara, and Zaller, John, "Sources of popular support for authoritarian regimes", American Journal of Political Science 33/2 (1989), 319-47. 
Gerschewski, Johannes, "The three pillars of stability: Legitimation, repression, and co-optation in autocratic regimes", Democratization 20/1 (2013), 13-38.

Gill, Graeme, Symbols and Legitimacy in Soviet politics (Cambridge: Cambridge University Press, 2011).

Gorenburg, Dmitry, "Soviet nationalities policy and assimilation", in Rebounding Identities: The Politics of Identity in Russia and Ukraine, Dominique Arel and Blair A. Ruble (eds.) (Washington, D.C.: Woodrow Wilson Center Press, and Baltimore, MD: Johns Hopkins University Press, 2006): 273-303.

Hertog, Katrien, "A self-fulfilling prophecy: The seeds of Islamic radicalisation in Chechnya", Religion, State and Society 33/3 (2005), 239-52.

Howard, Marc Morjé, and Roessler, Philip G., "Liberalizing electoral outcomes in competitive authoritarian regimes", American Journal of Political Science 50/2 (2006), $3^{6} 5^{-81 .}$

Hughes, James. "Chechnya: The causes of a protracted post-soviet conflict." Civil Wars 4, no. 4 (2001): 11-48.Isaacs, Rico, "Papa': Nursultan Nazarbayev and the discourse of charismatic leadership and nation-building in post-Soviet Kazakhstan", Studies in Ethnicity and Nationalism 10/3 (2010), 435-52.

Jäger, Siegfried, and Maier, Florentine, "Analysing discourses and dispositives: A Foucauldian approach to theory and methodology", In Methods of Critical Discourse Studies, Ruth Wodak and Michael Meyer (eds.) (London: Sage, 2016), 109-36.

Jeffries, Lesley, Textual Construction of the Female Body: A Critical Discourse Approach (New York: Springer, 2007).

Kailitz, Steffen, "Classifying political regimes revisited: legitimation and durability", Democratization 20/1 (2013), 39-6o.

Kailitz, Steffen, and Stockemer, Daniel, "Regime legitimation, elite cohesion and the durability of autocratic regime types", International Political Science Review 38/3 (2015), 332-48.

Kennedy-Lewis, Brianna L., "Using critical policy analysis to examine competing discourses in zero tolerance legislation: Do we really want to leave no child behind?" Journal of Education Policy 29/2 (2014), 165-94.

Kilderry, Anna, "Teachers in early childhood policy", Journal of Education Policy 29/2 (2014), 242-62.

Krastev, Ivan, "Paradoxes of the new authoritarianism", Journal of Democracy 22/2 (2011), 5-16.

Leckie, Alisa G., Kaplan, Suzanne E., and Rubinstein-Ávila, Eliane, "The need for speed: A critical discourse analysis of the reclassification of English language learners in Arizona", Language Policy 12/2 (2013), 159-76.

Leow, Anthony Chee Siong, "Policy-as-discourse and schools in the role of health promotion: The application of Bernstein's transmission context in policy analysis", Discourse: Studies in the Cultural Politics of Education 32/3 (2011), 309-28. 
Levitsky, Steven, and Way, Lucan, "The durability of revolutionary regimes", Journal of Democracy 24/3 (2013), 5-17.

Linz, Juan José, and Linz, Juan J., Totalitarian and Authoritarian Regimes (Boulder, CO: Lynne Rienner, 2000).

David, Machin, and Mayr, Andrea, How to Do Critical Discourse Analysis: A Multimodal Introduction (London: Sage, 2012).

Markwick, Roger, Rewriting History in Soviet Russia: The Politics of Revisionist Historiography 1956-1974 (New York: Springer, 2001).

Milliken, Jennifer, "The study of discourse in international relations: A critique of research and methods", European Journal of International Relations 5/2 (1999), $225^{-54}$.

Omelicheva, Mariya Y., "Authoritarian legitimation: assessing discourses of legitimacy in Kazakhstan and Uzbekistan", Central Asian Survey 35/4 (2016), 481-500.

Parker, Brenda, "Beyond the class act: gender and race in the 'creative city'discourse", Research in Urban Sociology 9 (2008), 201-32.

Pennebaker, James W., Rim, Bernard, and Paez, Dario, eds. Collective Memory of Political Events: Social Psychological Perspectives (Hove, UK: Psychology Press, 2013).

Perovic, Jeronim, The North Caucasus on the Brink Zurich (Zurich: ETH, Center for Security Studies, 2006).

Philo, Greg, "Can discourse analysis successfully explain the content of media and journalistic practice?" Journalism Studies 8/2 (2007), 175-96.

Ratelle, Jean-François, and Souleimanov, Emil Aslan, "A perfect counterinsurgency? Making sense of Moscow's policy of Chechenisation", Europe-Asia Studies 68/8 (2016), 1287-314.

Rogers, Rebecca, "Storied selves: A critical discourse analysis of adult learners' literate lives", Reading Research Quarterly 39/3 (2004), 272-305.

Russell, John, "Ramzan Kadyrov: The indigenous key to success in Putin's Chechenization strategy?" Nationalities Papers 36/4 (2008), 659-87.

Russell, John, "Case Study-Ramzan Kadyrov in Chechnya: Authoritarian leadership in the Caucasus", in The Faces of Terrorism: Multidisciplinary Perspectives, David V. Canter (ed.) (Chichester, UK: Wiley, 20o9), 2o9-26.

Russell, John, “Kadyrov's Chechnya: Template, test or trouble for Russia's regional policy?" Europe-Asia Studies 63/3 (2011), 509-28.

Schaefer, Robert W., The Insurgency in Chechnya and the North Caucasus: From Gazavat to Jihad (Santa Barbara, CA: Praeger, 2010).

Schedler, Andreas, The Politics of Uncertainty: Sustaining and Subverting Electoral Authoritarianism (Oxford: Oxford University Press, 2013).

Schleifer, Philip, and Bloomfield, Michael John, "When institutions fail:Legitimacy, (de) legitimation, and the failure of private governance systems". European University Institute Working Paper, 2015. 
Schudson, Michael, "The past in the present versus the present in the past", in The Collective Memory Reader, Jeffrey K. Olick, Vered Vinitzky-Seroussi, and Daniel Levy (eds.) (Oxford: Oxford University Press, 2011), 287-9o.

Scollon, Ron, "Mediated discourse and social interaction", Research on Language \& Social Interaction 32/-2 (1999): 149-54.

Screti, Francesco, "Defending joy against the popular revolution: Legitimation and delegitimation through songs”, Critical Discourse Studies 10/ 2 (2013), 205-22.

Sokirianskaia, Ekaterina, "Mozhno li predotvratit novye volny radikalizatsii na Severnom Kavkaze? Radikalizatsia i ee profilaktika v Chechne, Ingushetii, Dagestane i Kabardino-Balkarii. Centr Analiza i predotvrashcheniia konfliktov", Kavkazii Uzel, 30 January 2019. https://www.kavkaz-uzel.eu/articles/mojno_li_pre dotvratit_novie_radikalisazii/ (accessed 27 October 2020).

Souleimanov, Emil, “Russian Chechnya policy: 'Chechenization' turning into 'Kadyrovization'?", Central Asia-Caucasus Analyst 8/11 (2006), 3-5.

Souleimanov, Emil, "An ethnography of counterinsurgency: Kadyrovtsy and Russia's policy of Chechenization", Post-Soviet Affairs 31/2 (2015), 91-114.

Souleimanov, Emil Aslan, Abbasov, Namig, and Siroky, David S., "Frankenstein in Grozny: Vertical and horizontal cracks in the foundation of Kadyrov's rule", Asia Europe Journal 17/1 (2019), 87-103.

Souleimanov, Emil, and Ditrych, Ondrej, "The internationalisation of the RussianChechen conflict: Myths and reality", Europe-Asia Studies 6o/7 (2008), 1199-222.

Souleimanov, Emil Aslan, and Siroky, David S., "Random or retributive: Indiscriminate violence in the Chechen wars", World Politics 68 (2016): 677-712.

Steffek, Jens, "The legitimation of international governance: A discourse approach", European Journal of International Relations 9/2 (2003), 249-75.

Tota, Anna Lisa, “Collective memories at 'work': Tthe public remembering of contested pasts”, Comparative Social Research 21 (2003), 63-86.

Traynor, Ian, "Akhmad Kadyrov: Chechen president widely seen as Moscow puppet", The Guardian, 10 May 2004. https://www.theguardian.com/news/2004/may/10/ guardianobituaries.russia (accessed 27 October 2020).

Van Dijk, Teun A., "Principles of critical discourse analysis", Discourse \& Society 4/2 (1993), 249-83.

Van Dijk, Teun A., "Multidisciplinary CDA: A plea for diversity", in Methods of Critical Discourse Analysis, Ruth Wodak and Michael Meyer (eds.) (London: Sage, 2001), 95-120.

Van Dijk, Teun A., "Discourse and manipulation”, Discourse \& Society 17/3 (2006), 359-83.

Von Soest, Christian, and Grauvogel, Julia, "Comparing legitimation strategies in postSoviet countries", in Politics and Legitimacy in Post-Soviet Eurasia, Martin Brusis, 
Joachim Ahrens, and Martin Schulze Wessel (eds.) (London: Palgrave Macmillan, London, 2016), 18-46.

Von Soest, Christian, and Grauvogel, Julia, "Identity, procedures and performance: How authoritarian regimes legitimize their rule", Contemporary Politics 23/3 (2017), 287-305.

Ware, Robert Bruce, "Chechenization: Ironies and intricacies", Brown Journal of World Affairs 15/2 (2009), 157-69.

Wedeen, Lisa, Ambiguities of Domination: Politics, Rhetoric, and Symbols in Contemporary Syria (Chicago, IL: University of Chicago Press, 2015).

Wilhelmsen, Julie. Russia's securitization of Chechnya: how war became acceptable. Taylor \& Francis, 2016.Wilhelmsen, Julie, "Inside Russia's imperial relations: The social constitution of Putin-Kadyrov patronage”, Slavic Review 77/4 (2018), 919-36.

Williams, Brian Glyn. "Commemorating "the deportation" in post-Soviet Chechnya: the role of memorialization and collective memory in the 1994-1996 and 1999-2000 Russo-Chechen Wars." History \& Memory 12, no. 1 (2000): 101-134.Wood, Linda A., and Kroger, Rolf O., Doing Discourse Analysis: Methods for Studying Action in Talk and Text (London: Sage, 2000).

Wodak, Ruth, and Meyer, Michael, "Critical discourse studies: History, agenda, theory, and methodology", in Methods of Critical Discourse Studies, Ruth Wodak and Michael Meyer (eds.) (London: Sage, 2016), 1-22.

Yemelianova, Galina, "Islam, nationalism and state in the Muslim Caucasus", Caucasus Survey $1 / 2$ (2014), 3-23.

Zajda, Joseph, and Zajda, Rea, "The politics of rewriting history: New history textbooks and curriculum materials in Russia”, International Review of Education 49/3 (2003), $363-84$. 